ISSN 1392-3196 / e-ISSN 2335-8947

Zemdirbyste-Agriculture, vol. 104, No. 4 (2017), p. 337-344

DOI 10.13080/z-a.2017.104.043

\title{
The effect of stinging nettle and field horsetail extracts on the synthesis of biologically active compounds in germinated leguminous and quinoa seed
}

\author{
Honorata DANILČENKO ${ }^{1}$, Zenonas DABKEVIČIUS ${ }^{2}$, Elvyra JARIENE' ${ }^{1}$,

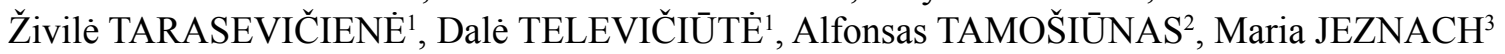

${ }^{1}$ Aleksandras Stulginskis University, Institute of Agricultural and Food Sciences

Studentų 11, Akademija, Kaunas distr., Lithuania

E-mail: zivile.taraseviciene@asu.lt_

${ }^{2}$ Aleksandras Stulginskis University, Institute of Biology and Plant Biotechnology

Studentų 11, Akademija, Kaunas distr., Lithuania

${ }^{3}$ Warsaw University of Life Sciences (SGGW)

Nowoursynowska 159C, bld. 32, 00-776 Warsaw, Poland

\begin{abstract}
The aim of this study was to evaluate the impact of aqueous extracts of stinging nettle (Urtica dioica L.) and field horsetail (Equisetum arvense L.) plants on the synthesis of compounds with antioxidant properties in germinating seeds. The seeds of alfalfa (Medicago sativa L.), dining lentil (Lens culinaris L.), mung bean (Vigna radiata L.) and quinoa (Chenopodium quinoa Willd.) were germinated for 72 hours. Germinating seeds were imbibed and daily soaked in aqueous stinging nettle and field horsetail plant extracts.

We studied the influence of elicitation on the amount of dry matter, anthocyanins, leucoanthocyanins and catechins as well as vitamin $\mathrm{C}, \mathrm{P}$ and antioxidant activity in germinated seeds.

During germination, $34.21 \%$ more intense synthesis of anthocyanins occurred in quinoa seeds treated with stinging nettle extract solutions compared with those treated with water only. Under the influence of extracts, the content of vitamin C significantly increased only in lentils, treated with stinging nettle extract by $40.65 \mathrm{mg}^{100 \mathrm{~g}^{-1}} \mathrm{fresh}$ weight (FW) and field horsetail extract by $42.48 \mathrm{mg} 100 \mathrm{~g}^{-1} \mathrm{FW}$, while in mung beans the increase was noticed

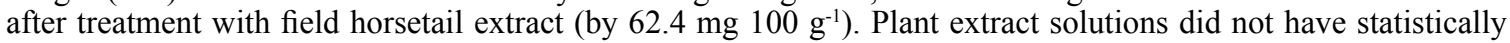
significant impact on vitamin $\mathrm{P}$ (rutin) accumulation in germinated seeds. However, a trend towards $\mathrm{P}$ increase was observed in all germinated seeds, except for alfalfa. Germinated alfalfa seeds and mung beans were characterized by the highest antioxidant activity.
\end{abstract}

Key words: antioxidant activity, antioxidant compounds, seeds, solutions.

\section{Introduction}

Germinated seeds may be used for the development of innovative products. Extensive breakdown of seed-storage compounds and synthesis of structural proteins and other cell components take place during the germination. During this process, an important role is played by the movement of metabolites from the tissues that have accumulated reserve substances into the growing (main) organs. During the germination process, bimolecular enzymatic reactions become more active, and starch, protein and fat are converted into simpler compounds (Yang et al., 2001).

Germination is considered both simple and economical to improve the nutritive value of legumes by causing desirable changes in the nutrient availability, texture and organoleptic characteristics, increasing the levels of free amino acids, available carbohydrates, dietary fibre and bioactive antioxidative compounds (López-Amorós et al., 2006).

Scientific publications conclude that sprouts have detoxifying properties, strengthen the human immune system and help eliminate free radicals from the body (Donkor et al., 2012).

Germination starts when the dry seed begins to take up water and is completed when the embryonic axis elongates. At this point, reserves within the storage tissues of the seed are mobilised to support seedling growth. From the moment the seed breaks dormancy, protective responses emerge through the synthesis of phenolics and other compounds (Gharachorloo et al., 2012). 
Approximately 8000 different structures of plant penolics are currently known. They are characterised by antioxidant properties and are recognized as secondary plant metabolites, thus comprising one of the largest groups of phytochemicals that can reduce the risk of chronic diseases (Ignat et al., 2011). The quantity and composition of phenolic compounds depend on the seed species and germination conditions.

Fernandez-Orozco et al. (2009) investigated the effect of germination on the improvement of the antioxidant properties of chickpeas. The results indicated that germination caused an increment in the total phenolic content, increased peroxyl radical-trapping capacity (16-55\%). Phenolic contents of 7-day old sprouts ranged from 490 (lentils) to 5676 (mustards) mg chlorogenic acid equivalent (CAE) $100 \mathrm{~g}^{-1}$ dry matter. Increases in phenolics from dormant seed to 7-day old sprout differed among seeds from $2010 \%$ (mung beans) to $11 \%$ (kale). Research results show that germinated edible seeds are an excellent source of dietary phenolic antioxidants (Yang et al., 2001; Cevallos-Casals, Cisneros-Zevallos, 2010).

In plants, flavonoids are involved in a variety of important processes related to germination, growth and reproduction. These compounds and their derived pigments have contributed to shaping our knowledge of modern genetics, providing colourful tools to investigate a number of central plant problems, including the biology of transposons, the regulation of gene expression, gene silencing, and the organization of metabolic pathways (Grotewold, 2005). The majority of them can be found in early sprouts, they differ not only in quantities, but also in composition. In addition to this, they are also characterised by antifungal, antimicrobial and antiviral effects (Cowan, 1999). Anthocyanins (anthocyanidins with sugar moieties) are a large group of water-soluble compounds that belongs to a class of flavonoids and is characterised by a health-promoting effect. Leopoldini et al. (2011) research results supported the hypothesis that anthocyanin synthesis may allow the plant to develop resistance to a number of elicitor treatments by stimulation of the phenylalanine ammonia-lyase (PAL) pathway.

Elicitors are substances which induce physiological changes in the plant. Plants respond to these stressors by activating an array of mechanisms, similar to the defence responses to pathogen infections or environmental stimuli, affecting the plant metabolism and enhancing the synthesis of different classes of phytochemicals (Baenas et al., 2014; Dueñas et al., 2015). Some plant extracts may function as a source of biological substances that stimulate the synthesis of compounds which have biologically active and health-promoting properties. Scientific studies have demonstrated that plants are able to recognise each other and can exchange information (Karban et al., 2000). This communication among plants takes place in a molecular level, and the role of signalling molecules is played by particular bioflavonoids. Apparently, flavonoids contained in plant extracts help recognise the same compounds, which results in a more intensive development of early sprouts. Dueñas et al. (2009) reported that germination caused significant changes in the phenolic composition (increasing) due mainly to endogenous enzymes activation and the complex biochemical metabolism of seeds during this process.
As a biotic natural elicitor, oregano extract increased antioxidant activity estimated by beta-carotene assay of two and four days germinated fenugreek seeds (Randhir et al., 2004). Elicitor solutions prepared of ascorbic acid and folic acid resulted in increase of total amount of phenolic compounds and antioxidant activity of germinated seeds (Burguieres et al., 2007). GawlikDziki et al. (2013) elicited broccoli seeds using the extracts of Saccharomyces cerevisiae and S. daphnoides bark for improvement of nutraceutical value of broccoli sprouts and showed significant increase of the antioxidant properties of sprouts. The values of total phenolic compounds and antioxidant activity obtained for wheat sprouts elicited by $S$. daphnoides bark extract were in most cases significantly higher than those received for the control sample (Dziki et al., 2015).

According to Garcia et al. (2012), field horsetail contains phenolic acids (apigenin 5-O-glucoside, methyl esthers of protocatechuic, 5-O-caffeoyl shikimic acid, monocaffeoyl meso-tartaric acid, dicaffeoyl meso-tartaric acid), flavonoids (quercetin, isoquercetin, quercetin 3-O-glucoside, quercetin 3-O-(6"-O-malonylglucoside), kaempferol 3-O-glycoside), that are distinguished by antioxidant properties. What is more, there are also some potassium salts and alkaloids including nicotine, various organic acids and rare dicarboxylic acids. Stinging nettle contains the followingflavonoids:kaempferol, isorhamnetin, quercetin, and their 3-rutinosides and 3-glycosides (Bucar et al., 2006). Stinging nettle leaves are rich in vitamins such as $\mathrm{C}$, the $\mathrm{B}$ group and $\mathrm{K}$, micronutrients; they also contain iron which regulates the movement of $\mathrm{K}$ and $\mathrm{Ca}$ in cells, and calcium, potassium, sodium, magnesium, boron, silicon which stimulate the immune system, and chlorophyll which activates the growth of plants. Stinging nettle greatly absorbs minerals from the soil, especially iron as it contains vitamin C (Upton, 2013). The chemical content of field horsetail and stinging nettle allows making assumptions that it may influence the synthesis of phytochemicals in germinating seeds.

The controlled short-time elicitation stresses, during the pre-harvest and post-harvest period, can be used as a tool by the fresh produce industry to obtain healthier products by enhancing their nutraceutical content (Baenas et al., 2014). Therefore the aim of this study was to establish the impact of plant extracts on the synthesis of compounds with antioxidant properties in germinating seeds for food.

\section{Materials and methods}

The research was carried out over the period of 2014-2015 at the Faculty of Agronomy, Aleksandras Stulginskis University. One hundred grams of seeds of alfalfa (Medicago sativa L.), dining lentil (Lens culinaris L.), mung bean (Vigna radiata L.) and quinoa (Chenopodium quinoa Willd.) were germinated in four replications. All chemical analyses were performed in triplicate analytical replications from four biological samples. Before germination, the seeds were carefully sorted by removing impurities and cracked seeds.

For seed soaking and moistening the water (control treatment) and aqueous extracts of dried stinging nettle (Urtica dioica L.) and field horsetail (Equisetum 
arvense L.) were used. Production of plant extract solutions: $10 \mathrm{~g}$ of dried horsetails / nettles were brewed up with 1.0 litre of boiled water. The contents were boiled for five minutes and then cooled. Freshly prepared plant extracts were used for each moistening. The seeds were soaked for $12 \mathrm{~h}$ in water (control) / plant extract solutions where seeds / extract ratio was 1:4. Seeds were germinated for $72 \mathrm{~h}$ at $22^{\circ} \mathrm{C}$ in the dark in a 1 litre germinator "Bio-natura" (Poland) of $20 \mathrm{~cm}$ in diameter. During germination, the seeds were moistened with water (control) and plant extracts every 12 hours.

The amount of dry matter (DM) in germinated seeds was determined by drying the samples at $105^{\circ} \mathrm{C}$ to a constant weight.

The concentration of the anthocyanin pigments was determined spectrophotometrically at 510 and $657 \mathrm{~nm}$ according to $\mathrm{pH}$ differential method with a spectrophotometer Shimadzu UV-3600 (Japan). The amount of anthocyanins was calculated as cyanidin-3glucoside equivalents (Чупахина, Масленников, 2004).

To determine the amount of leucoanthocyanins, the samples were ground to a homogeneous state in the presence of acidified $96^{\circ}$ ethanol (20:1) with hydrochloric acid, the homogenate was centrifuged at $4500 \mathrm{~g}$ for 30 min. One millilitre of extract was added to the tubes with $19 \mathrm{ml}$ of $5 \% \mathrm{HCl}$ in n-butanol and shaken. The tubes were heated in a boiling water bath for $50 \mathrm{~min}$ and cooled. The amount of leucoanthocyanins was determined spectrophotometrically at $520 \mathrm{~nm}$ with a Shimadzu UV3600 (Чупахина, Масленников, 2004).

For determination of catechins, the samples were ground to a homogeneous state in the presence of acidified $96^{\circ}$ ethanol (20:1) with hydrochloric acid, the homogenate was centrifuged at $5000 \mathrm{~g}$ for $10 \mathrm{~min}$. One millilitre $\mathrm{ml}$ of extract was added to the tubes with $4 \mathrm{ml}$ vanillyl reagent and hydrochloric acid $(2.5 \mathrm{ml} 5 \%$ alcoholic solution of vanillin with $47.5 \mathrm{ml} \mathrm{HCl}$ ). Measurements were performed with a Shimadzu UV-3600 at $520 \mathrm{~nm}$ after 5 min (Чупахина, Масленников, 2004).

Vitamin $\mathrm{C}$ and vitamin $\mathrm{P}$ (rutin) contents were determined by titrimetric methods using 2,6-dichlorophenolindophenol (ISO 6557-2:1984. Fruits, vegetables and derived products. Determination of ascorbic acid content. Part 2: Routine methods) and potassium permanganate, respectively (Чупахина, Масленников, 2004).

The radical scavenging activity of the samples and fractions against $\alpha$-diphenyl- $\beta$-picrylhydrazyl (DPPH) free radical was measured using the method of Yen and Chen (1995). The DPPH radical scavenging activity of extracts was calculated from the standard curve of Trolox and expressed as micromoles of Trolox equivalents (TE) per gram of sample $\left(\mu \mathrm{mol} \mathrm{g}^{-1} \mathrm{TE}\right)$.

Data were expressed as mean \pm standard deviation (SD) of three experiments with three determinations which represent analytical measurement. The results were subjected to a one-way analysis of variance, and the least significant difference (LSD) using Fisher's test at a significance level of $p<0.05$ was calculated. Statistical analysis was performed using software STATISTICA 10. The correlation-regression analysis was done to establish the nature and strength of the correlation between the variables.

\section{Results and discussion}

Sprouting of seeds can result in a decrease of total dry matter, an increase in total protein, a change in amino acid composition of the seeds, a decrease in starch content, an increase in sugars, a slight increase in crude fat and crude fibre, and slightly higher amounts of certain vitamins and minerals. During mitochondrial oxidation reactions, nutrients are broken down and biological energy is released (Chavan, Kadam, 1989).

During germination, field horsetail and stinging nettle solutions slightly increased the content of dry matter in all seeds, except for dining lentil (Table 1). During moistening of germinated seeds with field horsetail and stinging nettle solutions, the lowest content of dry matter was determined in alfalfa seeds and no significant difference was determined in other germinated seeds that were moistened with solutions. The content of dry matter was significantly higher by $3.62-4.19$ percentage units in mung beans treated with plant extracts compared with the control treatment.

Table 1. Amount of dry matter in germinated seeds (\%)

\begin{tabular}{|c|c|c|c|}
\hline \multirow{2}{*}{ Species of seeds } & \multicolumn{3}{|c|}{ Plant extract solutions } \\
\hline & control $\left(\mathrm{H}_{2} \mathrm{O}\right)$ & Urtica dioica & Equisetum arvense \\
\hline Vigna radiata & $26.87 \pm 1.65 \mathrm{aB}$ & $31.06 \pm 1.46 \mathrm{bB}$ & $30.49 \pm 2.78 \mathrm{bB}$ \\
\hline Medicago sativa & $16.78 \pm 2.54 \mathrm{aA}$ & $18.99 \pm 1.36 \mathrm{aA}$ & $18.41 \pm 2.36 \mathrm{aA}$ \\
\hline Lens culinaris & $31.82 \pm 0.69 \mathrm{aC}$ & $31.48 \pm 4.48 \mathrm{aB}$ & $30.60 \pm 3.42 \mathrm{aB}$ \\
\hline Chenopodium quinoa & $30.72 \pm 5.65 \mathrm{aB}$ & $35.09 \pm 1.62 \mathrm{aB}$ & $32.41 \pm 8.92 \mathrm{aB}$ \\
\hline
\end{tabular}

Note. Results are means \pm standard deviation; for used extracts, the same small letter in the same row means no significant difference $(P \leq 0.05)$ and for seeds species, the same capital letter in the same column means no significant difference $(P \leq 0.05)$.

During germination, the content of anthocyanins in seeds was influenced by the species of seeds and the plant extracts used (Table 2).

When moistening germinated seeds with plant extracts, a tendency of anthocyanin increase was observed compared to the control treatment. Upon water moistening, the highest content of anthocyanins was established in alfalfa, and the lowest content was found in mung bean seeds. The same tendency was observed when the seeds were moistened with stinging nettle and field horsetail solutions (Table 2). In mung bean and alfalfa seeds treated with field horsetail extract solution, the content of these compounds increased by $26.99 \%$ and $12.47 \%$, respectively compared with the control 
Table 2. Amount of anthocyanins and leucoanthocyanins in germinated seeds (mg $\left.100 \mathrm{~g}^{-1} \mathrm{DM}\right)$

\begin{tabular}{lcccccc}
\hline & \multicolumn{5}{c}{ Plant extract solutions } \\
\cline { 2 - 7 } \multicolumn{1}{c}{ Species of seeds } & \multicolumn{3}{c}{ anthocyanins } & \multicolumn{3}{c}{ leucoanthocyanins } \\
\cline { 2 - 7 } & control $\left(\mathrm{H}_{2} \mathrm{O}\right)$ & $\begin{array}{c}\text { Urtica } \\
\text { dioica }\end{array}$ & $\begin{array}{c}\text { Equisetum } \\
\text { arvense }\end{array}$ & control $\left(\mathrm{H}_{2} \mathrm{O}\right)$ & $\begin{array}{c}\text { Urtica } \\
\text { dioica }\end{array}$ & $\begin{array}{c}\text { Equisetum } \\
\text { arvense }\end{array}$ \\
\cline { 2 - 7 } Vigna radiata & $1.63 \pm 0.20 \mathrm{aA}$ & $1.36 \pm 0.17 \mathrm{aA}$ & $2.07 \pm 0.31 \mathrm{bA}$ & $60.09 \pm 0.73 \mathrm{cC}$ & $39.04 \pm 0.28 \mathrm{aA}$ & $54.79 \pm 0.28 \mathrm{bB}$ \\
Medicago sativa & $7.46 \pm 0.13 \mathrm{aD}$ & $8.12 \pm 0.64 \mathrm{bC}$ & $8.39 \pm 0.25 \mathrm{bC}$ & $40.63 \pm 0.44 \mathrm{aB}$ & $46.22 \pm 0.49 \mathrm{bA}$ & $52.49 \pm 0.45 \mathrm{cB}$ \\
Lens culinaris & $2.00 \pm 0.05 \mathrm{aB}$ & $2.04 \pm 0.14 \mathrm{aB}$ & $1.96 \pm 0.03 \mathrm{aA}$ & $68.82 \pm 10.44 \mathrm{aC}$ & $57.21 \pm 0.35 \mathrm{aA}$ & $64.73 \pm 8.35 \mathrm{aC}$ \\
Chenopodium quinoa & $6.46 \pm 0.06 \mathrm{aC}$ & $8.67 \pm 0.12 \mathrm{cC}$ & $7.35 \pm 0.14 \mathrm{bB}$ & $28.68 \pm 0.19 \mathrm{aA}$ & $53.17 \pm 0.34 \mathrm{cA}$ & $31.41 \pm 0.35 \mathrm{bA}$ \\
\hline
\end{tabular}

Explanations under Table 1

treatment. During germination, quinoa seeds treated with stinging nettle and field horsetail extracts showed a more intensive anthocyanin synthesis compared with the control treatments, the difference being $34.21 \%$. According to Paskó et al. (2009), the content of anthocyanins in quinoa seeds is $120.4 \mathrm{mg} 100 \mathrm{~g}$ DM. The seeds of the main commercial cultivars of quinoa are white or black in colour, quinoa grains may appear as yellow or redviolet and strong effort has been made to maintain and characterize the cultivars from the agronomical point of view (Gómez-Pando et al., 2010). In this research, germinated quinoa seeds were with yellow coating that influenced such a big difference compared with Paskó et al. (2009) findings.

Plant extracts used for moistening determined a more intensive synthesis of anthocyanins in all tested species of seeds, except for dining lentil (Table 2). Elicitors can stimulate different classes of secondary metabolites and affect in a different way the concentration of these compounds, being more dependent on plant genetics (species and cultivars) than on the elicitor nature (Baenas et al., 2014).

Accumulation of leucoanthocyanins in the seeds was determined by the species of seeds; when the seeds were treated only with water, the highest content of these compounds was found in mung beans and lentils, i.e. 60.09 and $68.82 \mathrm{mg} 100 \mathrm{~g}^{-1}$, respectively, while the lowest content was found in quinoa seeds, which was $28.68 \mathrm{mg} 100 \mathrm{~g}^{-1}$ (Table 2). Stinging nettle extract increased the amount of leucoanthocyanins in germinated quinoa and alfalfa seeds compared with the control treatments. In the seeds treated with field horsetail extract solution, the content of leucoanthocyanins varied from 31.41 to $64.73 \mathrm{mg} 100 \mathrm{~g} \mathrm{~g}^{-1}$. The highest content of leucoanthocyanins was found in lentils; however, treatment with different extracts did not have significant impact. The content of leucoanthocyanins in quinoa seeds treated with stinging nettle extract was higher by $85.39 \%$ compared with the control treatment. Field horsetail extract had significant impact on the content of leucoanthocyanins in the germinated quinoa and alfalfa seeds. After treating the seeds with field horsetail extract, the contents of leucoanthocyanins in quinoa and alfalfa seeds increased by $9.52 \%$ and $29.19 \%$, respectively.

There was not observed a clear tendency in leucoanthocyanin accumulation depending on the plant extracts used (Table 2).

Catechins are a group of polyphenolic compounds belonging to flavonoid class whose high concentrations can be found in fresh tea leaves, red wine, broad beans, black grapes, apricots and strawberries. Biological properties of catechins include antibacterial, anticarcinogenic, antimutagenic activity as well as anti-inflammatory and antioxidant effect (Gadkaria, Balaramana, 2015). In our study, the concentration of catechins in the tested species of seeds showed a statistically significant difference. Their highest contents were found in the seeds of bean family plants, lentils and mung beans -86.88 and $64.58 \mathrm{mg}$ $100 \mathrm{~g}^{-1}$, respectively (Table 3 ).

Table 3. The amount of catechins in germinated seeds (mg $\left.100 \mathrm{~g}^{-1} \mathrm{DM}\right)$

\begin{tabular}{lccr}
\hline \multirow{2}{*}{ Species of seeds } & \multicolumn{3}{c}{ Plant extract solutions } \\
\cline { 2 - 4 } & control $\left(\mathrm{H}_{2} \mathrm{O}\right)$ & Urtica dioica & Equisetum arvense \\
\hline Vigna radiata & $64.58 \pm 0.33 \mathrm{bC}$ & $45.47 \pm 0.40 \mathrm{aB}$ & $95.07 \pm 0.30 \mathrm{cC}$ \\
Medicago sativa & $37.51 \pm 0.30 \mathrm{aB}$ & $53.22 \pm 0.19 \mathrm{bC}$ & $71.10 \pm 0.17 \mathrm{cA}$ \\
Lens culinaris & $86.88 \pm 0.14 \mathrm{cD}$ & $40.88 \pm 0.36 \mathrm{aA}$ & $79.04 \pm 0.14 \mathrm{bB}$ \\
Chenopodium quinoa & $21.48 \pm 0.19 \mathrm{aA}$ & $68.97 \pm 0.80 \mathrm{bD}$ & $179.16 \pm 0.63 \mathrm{cD}$ \\
\hline
\end{tabular}

Explanations under Table 1

The content of catechins in the seeds treated with stinging nettle and field horsetail extracts was influenced by genetic characteristics of the plant. The highest content of catechins was found in the quinoa seeds treated with the extracts of both plants $(8.3$-fold increase) compared with the control treatment. Stinging nettle extract solution decreased the content of catechins in the seeds of bean family plants: in mung beans - by 1.4 times and in lentils - by 2.1 times. Field horsetail extract solution statistically significantly increased the content of catechins in all the tested species of seeds, except for dining lentil, but the highest concentration of catechins was found in the control treatment (Table 3).

Rocha-Guzman et al. (2007) found out that, depending on the cultivar, the content of catechins in non-germinated bean seeds may vary from 11.23 to 16.94 $\mathrm{mg} \mathrm{g}^{-1}$ in 50\% methanol extract. According to FernandezOrozco et al. (2008), in germinating quinoa seeds, the 
content of catechins increased from 1.09 to $3.46 \mathrm{mg}$ $\mathrm{g}^{-1}$ DM. Catechin content increased during elicitation with all investigated plant extracts with the exception of lentils and mung beans elicited with a stinging nettle extract (Table 3).

Ascorbic acid is an important metabolite involved in many cellular processes, including cell division (Asard et al., 2003). Ascorbate has been shown to play multiple roles in plant growth, such as cell division, cell wall expansion and other developmental processes. It can act as a coenzyme for numerous metabolic enzymes and has recently been shown to be a potent antioxidant. Intensity of vitamin $\mathrm{C}$ formation was determined by the plant species (Fig. 1). The highest content of this compound was found in alfalfa seeds and the lowest one in quinoa seeds. The content of vitamin $\mathrm{C}$ did not differ significantly in the seeds of lentils and mung beans. Under the influence of extracts, the content of vitamin $\mathrm{C}$ increased statistically only in lentils ( 40.65 and $42.48 \mathrm{mg}$ $100 \mathrm{~g}^{-1}$, respectively), while in mung beans the increase was noticed after moistening with field horsetail extract

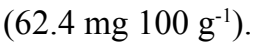

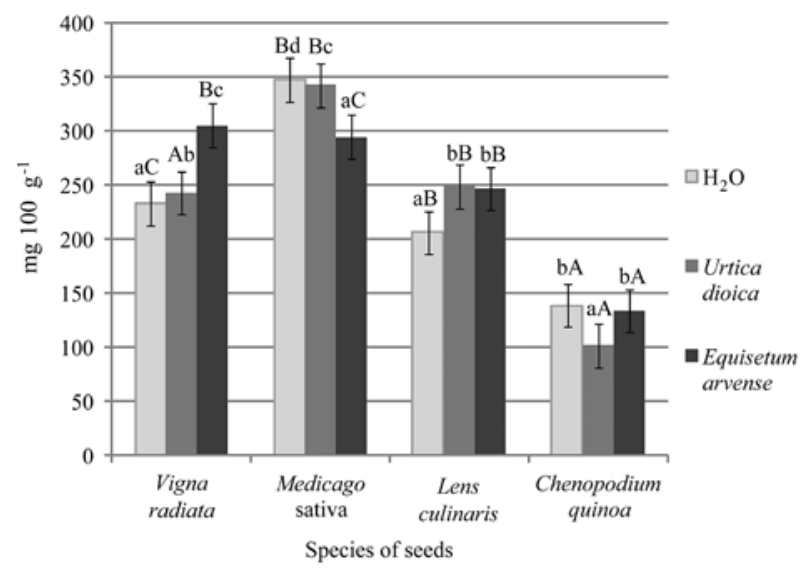

Note. For used extracts the same small letter means no significant difference $(P \leq 0.05)$ and for seed species the same capital letter means no significant difference $(P \leq 0.05)$; results are means \pm standard deviation.

Figure 1. Amount of vitamin C mg $100 \mathrm{~g}^{-1}$ fresh matter (FM) in germinated seeds

Fernandez-Orozco et al. (2008) have found that in germinating mung bean seeds, the content of vitamin $\mathrm{C}$ increased from 1.86 to $9.07 \mathrm{mg} 100 \mathrm{~g}^{-1} \mathrm{DM}$. The tested seeds were germinated in the dark. The data of Asard et al. (2003) suggest that darkness could stimulate vitamin $\mathrm{C}$ formation, due to the increased amounts of reducing sugars resulting from enhanced amylolysis. What is more, organic acids present in stinging nettle and field horsetail could have also stimulated this process.

Research has shown that vitamin P (rutin) flavonol glycoside has influence on vascular elasticity (Mukoda et al., 2001). Rutin is a powerful antioxidant with anti-inflammatory activity, and exerts renalprotective effects on the ischemia / reperfusion induced renal injury, ethanol-induced gastric injury, has also anticonvulsant effects in the brain (Uivarosi et al., 2010). The content of vitamin $\mathrm{P}$ in germinated seeds was not statistically significantly influenced either by the plant species or by moistening of seeds with plant extract solutions (Fig. 2). However, there was not observed a tendency towards its content increasing in all germinated seeds, except for alfalfa.

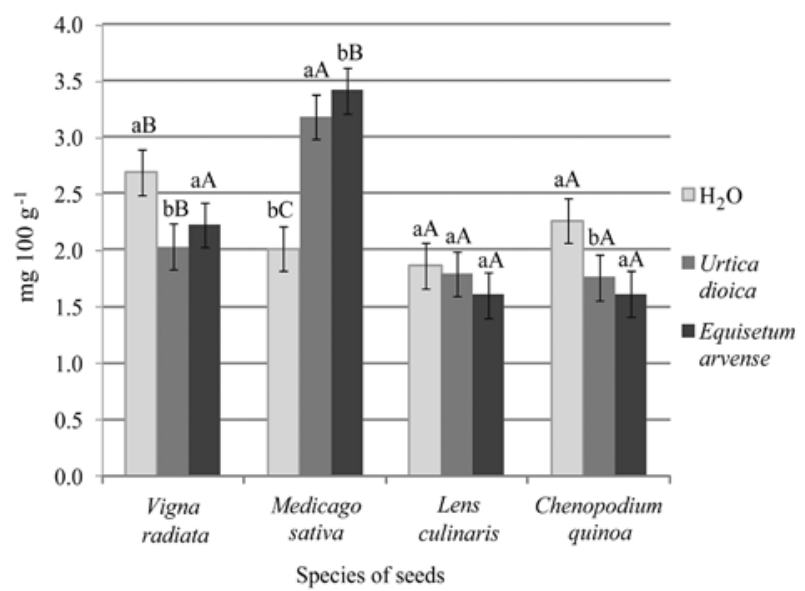

Note. For used extracts the same small letter means no significant difference $(P \leq 0.05)$ and for seed species the same capital letter means no significant difference $(P \leq 0.05)$; results are means \pm standard deviation.

Figure 2. The amount of vitamin $\mathrm{P}$ (rutin) $\mathrm{mg} 100 \mathrm{~g}^{-1}$ fresh matter (FM) in germinated seeds

The content of vitamin $\mathrm{P}$ varied from 1.60 to $3.41 \mathrm{mg} 100 \mathrm{~g}^{-1}$ in the seeds germinated for 72 hours. It is assumed that the slight increase may be associated with a more active vitamin synthesis which is necessary for the plant body due to the production of metabolic compounds. It is argued that buckwheat sprouts are a good source of these compounds as their content increases by 14.37$204.88 \%$ (from 11.68 to $35.61 \mathrm{mg} \mathrm{g}^{-1} \mathrm{DM}$ ) as compared to the content of rutin in non-germinated seeds (Kim et al., 2007). Even though rutin is widely distributed in plants, its content is low in edible plant parts. Small quantities of this compound are found in cereals, quinoa and amaranth (Zhou et al., 2015).

According to López-Amorós et al. (2006), peas and beans undergo a significant increase in antioxidant activity after germination, whereas lentils show a decrease. Dueñas et al. (2009) has concluded that germination is a good process to produce significant changes in the amounts of antioxidant compounds.

Assessment of the antioxidant activity results of the biologically active compounds in germinated seeds using the DPPH method showed that alfalfa and mung beans were characterized by the highest antioxidant activity (Table 4). We established positive influence of both plant extract solutions on the antioxidative capacity of the testes seed species compared with the control. Our studies showed that the greatest positive effect on the antioxidant activity of all tested seeds was exerted by the field horsetail extract solution. Its application resulted in significantly the highest $\left(28.03 \mu \mathrm{mol} \mathrm{\textrm {g } ^ { - 1 }}\right.$ TE) antioxidant activity of germinated quinoa seeds. While in germinated dining lentil seeds, the significant effect of plant extract solution was essentially the 
Table 4. Total antioxidant capacity of the germinated seeds elicited with plant extract solutions ( $\left.\mu \mathrm{mol} \mathrm{g}^{-1} \mathrm{TE} \mathrm{DM}\right)$

\begin{tabular}{lccc}
\hline \multirow{2}{*}{ Species of seeds } & \multicolumn{3}{c}{ Plant extract solutions } \\
\cline { 2 - 4 } & control $\left(\mathrm{H}_{2} \mathrm{O}\right)$ & Urtica dioica & Equisetum arvense \\
\hline Lens culinaris & $15.01 \mathrm{bB}$ & $16.47 \mathrm{bA}$ & $18.47 \mathrm{cA}$ \\
Medicago sativa & $19.24 \mathrm{aC}$ & $21.26 \mathrm{bA}$ & $22.40 \mathrm{bB}$ \\
Vigna radiata & $22.20 \mathrm{aD}$ & $24.32 \mathrm{bC}$ & $25.26 \mathrm{bC}$ \\
Chenopodium quinoa & $12.05 \mathrm{bA}$ & $16.02 \mathrm{cA}$ & $28.03 \mathrm{dC}$ \\
\hline
\end{tabular}

Explanations under Table 1

same and varied from $15.01 \mu \mathrm{mol} \mathrm{g} \mathrm{g}^{-1} \mathrm{TE}$ in control to $18.47 \mu \mathrm{mol} \mathrm{g}^{-1} \mathrm{TE}$ in field horsetail plant extract solution (Table 4). A weak positive relationship was established between the antioxidant activity, assayed by the DPPH method, and the contents of leucoanthocyanins, catechins and anthocyanins (respectively $r=0.430, r=0.516$, $r=0.425 ; p<0.05$ ). It is likely that a significant increase in antioxidant activity was associated with the composition of field horsetail extract. According to CetojevićSimin et al. (2010), field horsetail contains more than $10 \%$ inorganic substances (two-thirds of which are silicic acid and potassium salts). The results obtained suggest that the field horsetail extracts could be used as an easily accessible source of natural antioxidants and as potential phytochemicals (Cetojević-Simin et al., 2010, Romano et al., 2013). Frias et al. (2005) also have indicated that vitamin $C$ increased sharply but gradually after germination and this processes caused a significant increase in Trolox equivalent antioxidant capacity (TEAC).

During seed sprouting, a multitude of biochemical processes take place, leading to radical changes in the composition of primary and secondary metabolites, which could result in a change of intrinsic phenolic compounds profile, and antioxidant activity (Jian et al., 2009). Germination has been shown to be a very effective process to reduce antinutritional factors and increase bioactive phenolic compounds and antioxidant activities of seeds (Aguilera et al., 2013). Good antioxidant activity, for example, in quinoa seeds, may also be attributed to the presence of vitamin $\mathrm{C}$ and tocopherols (Paśko et al., 2009; Tang et al., 2015) which also protects against oxidation of its fatty acids.

\section{Conclusions}

1. The solutions of stinging nettle (Urtica dioica L.) and field horsetail (Equisetum arvense L.) extracts promoted synthesis of anthocyanins in germinating quinoa (Chenopodium quinoa Willd.) seeds, while the solution of field horsetail extract stimulated vitamin $\mathrm{C}$ synthesis in mung bean (Vigna radiata $\mathrm{L}$.) and dining lentil (Lens culinaris L.).

2. The solution of field horsetail extract significantly stimulated accumulation of catechins in the three out of the four tested species of seeds, except for dining lentil.

3. The application of solutions of plant extracts did not result in a significant increase in vitamin $\mathrm{P}$ (rutin) in all seeds, except for alfalfa (Medicago sativa $\mathrm{L}$.).

4. The germinated alfalfa and mung bean seeds were characterized by the highest antioxidant activity.

\section{Acknowledgments}

The authors are thankful to M.Sc. Oksana Kubiliūte for her technical assistance.

Received 08052017 Accepted 02102017

\section{References}

1. Aguilera Y., Díaz M. F., Jiménez T., Benítez V., Herrera T., Cuadrado C., Martín-Pedrosa M., Martín-Cabrejas M. A. 2013. Changes in nonnutritional factors and antioxidant activity during germination of nonconventional legumes. Journal of Agricultural and Food Chemistry, 61 (34): 8120-8125. https://doi.org/10.1021/jf4022652

2. Asard H., Smirnoff J., May N. 2003. Vitamin C: its function and biochemistry in animals and plants, p. 83-95.

3. Baenas N., García-Viguera C., Moreno D. A. 2014. Elicitation: a tool for enriching the bioactive composition of foods. Molecules, 19 (9): 2-6. https://doi.org/10.3390/molecules 190913541

4. Bucar F., Britzmann B., Streit B., Weigend M. 2006. LCPDA-MS-profiles of phenolic compounds in extracts aerial parts of Urtica species. Planta Medica, 72: 1028-1028.

5. Burguieres E., McCue P., Know Y. I., Shetty K. 2007. Effect of vitamin $\mathrm{C}$ and follic acid on seed vigour response and phenolic-linked antioxidant activity. Bioresource Technology, 98 (7): 1393-1404.

https://doi.org/10.1016/j.biortech.2006.05.046

6. Cetojević-Simin D. D., Canadanović-Brunet J. M., Bogdanović G. M., Djilas S. M., Cetković G. S., Tumbas V. T., Stojiljković B. T. 2010. Antioxidative and antiproliferative activities of different horsetail (Equisetum arvense L.) extracts. Journal of Medicinal Food, 13 (2): 452-9. https://doi.org/10.1089/jmf.2008.0159

7. Cevallos-Casals B. A., Cisneros-Zevallos L. 2010. Impact of germination on phenolic content and antioxidant activity of 13 edible seed species. Food Chemistry, 119 (4): 1485-1490.

https://doi.org/10.1016/j.foodchem.2009.09.030

8. Chavan J. K., Kadam S. S. 1989. Nutritional improvement of cereals by sprouting. Critical Reviews Food Science Nutrition, 28 (5): 401-437. https://doi.org/10.1080/10408398909527508

9. Cowan M. M. 1999. Plant products as antimicrobial agents. Clinical Microbiology Reviews, 12: 564-582.

10. Donkor O. N., Stojanovska L., Ginn P., Ashton J., Vasiljevic T. 2012. Germinated grains - sources of bioactive compounds. Food Chemistry, 135 (3): 950-959. https://doi.org/10.1016/j.foodchem.2012.05.058

11. Dueñas M., Hernández T., Estrella I., Fernández D. 2009. Germination as a process to increase the polyphenol content and antioxidant activity of lupin seeds (Lupinus angustifolius L.). Food Chemistry, 117 (4): 599-607. https://doi.org/10.1016/j.foodchem.2009.04.051 
12. Dziki D., Gawlik-Dziki U., Kordowska-Wiater M., DomanPytka M. 2015. Influence of elicitation and germination conditions on biological activity of wheat sprouts. Journal of Chemistry, 2015 (29): 1-8.

https://doi.org/10.1155/2015/649709

13. Fernandez-Orozco R., Frias J., Zielinski H., Piskula M. K., Kozlowska H., Vidal-Valverde C. 2008. Kinetic study of the antioxidant compounds and antioxidant capacity during germination of Vigna radiata cv. Emmerald, Glycine max cv. Jutro and Glycine max cv. Merit. Food Chemistry, 111 (3): 622-630. https://doi.org/10.1016/j.foodchem.2008.04.028

14. Fernandez-Orozco R., Frias J., Zielinski H., Munoz M., Piskula M. K., Kozlowska H., Vidal-Valverde C. 2009. Evaluation of bioprocesses to improve the antioxidant properties of chickpeas. European Food Research Technology, 42: 885-892.

15. Frias J., Miranda M. L., Doblado R., Vidal-Valverde C. 2005. Effect of germination and fermentation on the antioxidant vitamin content and antioxidant capacity of Lupinus albus L. var. Multolupa. Food Chemistry, 92 (2): $211-220$ https://doi.org/10.1016/j.foodchem.2004.06.049

16. Gadkaria P. V., Balaramana M. 2015. Catechins: sources, extraction and encapsulation: a review. Food and Bioproducts Processing, 93: 122-138.

17. Garcia D., Ramos A. J., Sanchis V., Marin S. 2012. Effect of Equisetum arvense and Stevia rebaudiana extracts on growth and mycotoxin production by Aspergillus flavus and Fusarium verticillioides in maize seeds as affected by water activity. International Journal of Microbiology, 153: $21-27$

18. Gawlik-Dziki U., Swieca M., Dziki D., Sugier D. 2013. Improvement of nutraceutical value of broccoli sprouts by natural elicitors. Acta Scientiarum Polonorum, Hortorum Cultus, 12 (1): 129-140.

19. Gharachorloo M., Tarzi B. G., Baharinia M., Hemaci A. H. 2012. Antioxidant activity and phenolic content of germinated lentil (Lens culinaris). Journal of Medicinal Plants Research, 6 (30): 4562-4566.

20. Gómez-Pando L. R., Álvarez-Castro R., Eguiluz-de la Barra A. 2010. Effect of salt stress on Peruvian germplasm of Chenopodium quinoa Willd.: a promising crop. Journal of Agronomy and Crop Science, 196 (5): 391-396. https://doi.org/10.1111/j.1439-037X.2010.00429.x

21. Grotewold E. 2005. Plant metabolic diversity: a regulatory perspective. Trends in Plant Science, 10 (2): 57-62. https://doi.org/10.1016/j.tplants.2004.12.009

22. Ignat I., Volf I., Popa V. I. 2011. A critical review of methods for characterisation of polyphenolic compounds in fruits and vegetables. Food Chemistry, 126 (4): 1821-1835. https://doi.org/10.1016/j.foodchem.2010.12.026

23. Jian G. X., Cheng R. T., Qing P. H., Ji Y. L., Xiang D. W., Xiang D. T. 2009. Dynamic changes in phenolic compounds and antioxidant activity in oats (Avena nuda L.) during steeping and germination. Journal of Agricultural and Food Chemistry, 57 (21): 10392-10398. https://doi.org/10.1021/jf902778j

24. Karban R., Baldwin I. T., Baxter K. J., Laue G. 2000 Communication between plants: induced resistance in wild tobacco plants following clipping of neighboring sagebrush. Oecologia, 125: 66-71.

25. Kim S.-J., Zaidul I. S. M., Maeda T., Suzuki T., Hashimoto N., Takigawa S., Noda T., Matsuura-Endo C., Yamauchi H. 2007. Time-course study of flavonoids in the sprouts of tartary (Fagopyrum tataricum Gaertn.) buckwheats. Scientia Horticulturae, 115: 13-18.
26. Leopoldini M., Russo N., Toscano M. 2011. The molecular basis of working mechanism of natural polyphenolic antioxidants. Food Chemistry, 125 (2): 288-306. https://doi.org/10.1016/j.foodchem.2010.08.012

27. López-Amorós M. L., Hernández T., Estrella I. 2006. Effect of germination on legume phenolic compounds and their antioxidant activity. Journal of Food Composition and Analysis, 19 (4): 277-283. https://doi.org/10.1016/j.jfca.2004.06.012

28. Mukoda T., Sun B., Ishiguro A. 2001. Antioxidant activities of buckwheat hull extract toward various oxidative stress in vitro and in vivo. Biological and Pharmaceutical Bulletin, 24 (3): 209-213. https://doi.org/10.1248/bpb.24.209

29. Paskó P., Bartoń H., Zagrodzki P., Gorinstein S., Fołta M., Zachwieja Z. 2009. Anthocanins, total polyphenols and antioxidant activity in amaranth and quinoa seeds and sprouts during their growth. Food Chemistry, 115 (3): 994-998. https://doi.org/10.1016/j.foodchem.2009.01.037

30. Randhir R., Lin Y. T., Shetty K. 2004. Stimulation of phenolics, antioxidant and antimicrobial activities in dark germinated mung bean sprouts in response to peptide and phytochemical elicitors. Journal of Process Biochemistry, 39: 637-646.

31. Rocha-Guzman N. E., Herzog A., Gonzalez-Laredo R. F., Ibarra-Perez F. J., Zambrano-Galvan G., GallegosInfante J. A. 2007. Antioxidant and mutagenic activity of phenolic compounds in three different colour groups of common bean cultivars (Phaseolus vulgaris). Food Chemistry, 103 (2): 521-527. https://doi.org/10.1016/j.foodchem.2006.08.021

32. Romano B., Pagano E., Montanaro V., Fortunato A. L., Milic N., Borrelli F. 2013. Novel insights into pharmacology of flavonoids. Phytotherapy Research, 27 (11): 1588-1596. https://doi.org/10.1002/ptr.5023

33. Tang Y., Li X., Zhang B., Chen P. X., Liu R., Tsao R. 2015. Characterisation of phenolics, betanins and antioxidant activities in seeds of three Chenopodium quinoa Willd. genotypes. Food Chemistry, 166: 380-388.

34. Uivarosi V., Barbuceanu S. F., Aldea V., Arama C. C., Badea M., Olar R., Marinescu D. 2010. Synthesis, spectral and thermal studies of new rutin vanadyl complexes. Molecules, 15 (3): 1578-1589. https://doi.org/10.3390/molecules 15031578

35. Upton R. 2013. Stinging nettles leaf (Urtica dioica L.): extraordinary vegetable medicine. Journal of Herbal Medicine, 3: 9-38.

36. Yang F., Basu T. K., Ooraikul B. 2001. Studies on germination conditions and antioxidant contents of wheat grain. International Journal of Food Sciences and Nutrition, 52 (4): 319-330. https://doi.org/10.1080/09637480120057567

37. Yen G. C., Chen H. Y. 1995. Antioxidant activity of various tea extracts in relation to their antimutagenicity. Journal of Agricultural and Food Chemistry, 43 (1): 27-32. https://doi.org/10.1021/jf00049a007

38. Zhou Y., Wang H., Cui L., Zhou X., Tang W., Song X. 2015. Evolution of nutrient ingredients in tartary buckwheat seeds during germination. Food Chemistry, 186: 244-248.

39. Чупахина Г. Н., Масленников П.В. 2004. Методы определения витаминов: практикум. Калининград, 36 с. (in Russian). 
ISSN 1392-3196 / e-ISSN 2335-8947

Zemdirbyste-Agriculture, vol. 104, No. 4 (2017), p. 337-344

DOI 10.13080/z-a.2017.104.043

\title{
Didžiųjų dilgẻlių ir dirvinių asiūklių ekstraktų poveikis biologiškai aktyvių junginių sintezei daigintose pupinių augalų ir bolivinių balandų sẻklose
}

\author{
H. Danilčenko ${ }^{1}$, Z. Dabkevičius ${ }^{2}$, E. Jarienè ${ }^{1}$, Ž. Tarasevičiené $\dot{1}^{1}$, D. Televičiūté1, \\ A. Tamošiūnas ${ }^{2}$, M. Jeznach ${ }^{3}$ \\ ${ }^{1}$ Aleksandro Stulginskio universiteto Žemès ūkio ir maisto mokslų institutas \\ ${ }^{2}$ Aleksandro Stulginskio universiteto Biologijos ir augalų biotechnologijos institutas \\ ${ }^{3}$ Varšuvos gyvybès mokslų universitetas
}

\section{Santrauka}

Tyrimo tikslas - įvertinti didžiosios dilgèlès (Urtica dioica L.) ir dirvinio asiūklio (Equisetum arvense L.) vandeninių ekstraktų poveikị antioksidacinėmis savybėmis pasižyminčių junginių sintezei daiginamose sẻklose. Mèlynžiedès liucernos (Medicago sativa L.), valgomojo lęšio (Lens culinaris L.), spindulinès pupuolès (Vigna radiata L.) ir bolivinès balandos (Chenopodium quinoa Willd.) sèklos buvo daigintos 72 valandas $22^{\circ} \mathrm{C}$ temperatūroje tamsoje. Dygstančios sèklos kasdien drèkintos vandeniniais dirvinio asiūklio ir didžiosios dilgèlès ekstraktais.

Daiginimo metu daugiausia antocianinų nustatyta bolivinių balandų sèklose, drèkintose dilgèlių ekstraktu, lyginant su sẻklomis, drékintomis tik vandeniu. Vitamino C kiekis daigintuose lęšiuose, drékintuose dilgèlių ekstraktu, esmingai padidejjo iki 40,65 mg $100 \mathrm{~g}^{-1}$, asiūklių ekstraktu - iki 42,48 mg $100 \mathrm{~g}^{-1}$, o spindulinėse pupuolèse, drèkintose asiūklių ekstraktu - iki $62,4 \mathrm{mg} 100 \mathrm{~g}^{-1}$. Augalų ekstraktai daigintose sẻklose neturèjo esminès ịtakos vitamino P (rutino) kiekiui, tačiau nustatyta tendencija, kad daigintose sẻklose, apdorotose augalų ekstraktais, jo kiekis didèja, išskyrus liucernas. Didžiausias antioksidacinis aktyvumas buvo būdingas daigintoms liucernų ir spindulinių pupuolių sėkloms.

Reikšminiai žodžiai: antioksidacinis aktyvumas, antioksidaciniai junginiai, sėklos, tirpalai. 